\title{
Strontium concentrations and isotope ratios in a forest-river system in the South Qinling Mts., China
}

\author{
Hongmei Bu ${ }^{\mathrm{a}, *}$, Xianfang Song a , Quanfa Zhang ${ }^{\mathrm{b}}$, Michele A. Burford ${ }^{\mathrm{c}}$ \\ ${ }^{a}$ Key Laboratory of Water Cycle and Related Land Surface Processes, Institute of Geographic Sciences and Natural Resources Research, Chinese Academy of \\ Sciences, Beijing, 100101, China \\ ${ }^{\mathrm{b}}$ Key Laboratory of Aquatic Botany and Watershed Ecology, Wuhan Botanical Garden, Chinese Academy of Sciences, Wuhan, 430074, China \\ c Australian Rivers Institute, Griffith University, Nathan, Qld, 4111, Australia
}

\section{A R T I C L E I N F O}

\section{Article history:}

Received 1 November 2015

Received in revised form

27 January 2016

Accepted 30 January 2016

Available online 12 February 2016

\section{Keywords:}

Forested catchment

$\mathrm{Sr}$

${ }^{87} \mathrm{Sr} /{ }^{86} \mathrm{Sr}$

$\mathrm{Ca} / \mathrm{Na}$

$\mathrm{Ca} / \mathrm{K}$

Source contribution

\begin{abstract}
A B S T R A C T
The concentrations of dissolved strontium ( $\mathrm{Sr}$ ) and isotope ratios $\left({ }^{87} \mathrm{Sr} /{ }^{86} \mathrm{Sr}\right)$ in rainwater, river water, and water from forest soil are measured to investigate the contributions of these sources to a river during base flow conditions in the relatively pristine South Qinling Mountains, China. Dissolved Sr concentrations and ${ }^{87} \mathrm{Sr} /{ }^{86} \mathrm{Sr}$ ratios vary significantly between different water types $(p<0.01)$ suggesting that it is suitable for differentiating sources. Dissolved $\mathrm{Sr}$ is also positively correlated with most ions and a range of physicochemical parameters ( $p<0.01$ and $p<0.05$ respectively) in water samples including $\mathrm{Ca}^{2+}$, $\mathrm{Mg}^{2+}, \mathrm{EC}$, and TDS $(p<0.001)$ indicating their similarities in the drivers of biogeochemical processes and common origins. The correlations between $\mathrm{Sr}$ isotopes and $\mathrm{Ca} / \mathrm{Na}, \mathrm{Ca} / \mathrm{K}$, and $1000 / \mathrm{Sr}$ ratios suggest that three end-members of atmospheric inputs, carbonate and silicate weathering control the $\mathrm{Sr}$ water chemistry in the river water. Using the three-source mixing model, atmospheric inputs, carbonate, and silicate weathering contribute $74 \%, 20 \%$, and $6 \%$ respectively to the dissolved $\mathrm{Sr}$ in the river water. This research has provided new insights into the contribution of sources of $\mathrm{Sr}$ to a river system in a mountainous catchment.
\end{abstract}

๑) 2016 Elsevier Ltd. All rights reserved.

\section{Introduction}

Natural strontium ( $\mathrm{Sr}$ ) isotopes have been proved to be useful tools for tracing the past and for monitoring present-day environmental processes (Bain and Bacon, 1994; Åberg, 1995; Shand et al., 2009). The geochemical behaviour of $\mathrm{Sr}$ is generally similar to that of Ca (Aubert et al., 2002), but is different from that of the alkali elements $\mathrm{K}$ and $\mathrm{Na}$. The $\mathrm{Sr}$ isotopic ratios $\left({ }^{87} \mathrm{Sr} /{ }^{86} \mathrm{Sr}\right)$ of natural materials reflect the sources of $\mathrm{Sr}$ available during their formation (Capo et al., 1998). Additionally, ${ }^{87} \mathrm{Sr} /{ }^{86} \mathrm{Sr}$ ratios are ideal source tracers because these isotopes have quite small fractionation during biogeochemical cycling (Pett-Ridge et al., 2009; Shand et al., 2009). One study found that the concentration of Sr varied from $\sim 6$ to $800 \mu \mathrm{g} \mathrm{L}^{-1}$, and averaged $\sim 60 \mu \mathrm{g} \mathrm{L}^{-1}$ in a river water system (Stallard, 1985), whereas another study found that the global river average was $78 \mu \mathrm{g} \mathrm{L}^{-1}$ (Palmer and Edmond, 1992). Strontium

\footnotetext{
* Corresponding author. Institute of Geographic Sciences and Natural Resource Research, Chinese Academy of Sciences, Datun Road, A 11, Beijing, 100101, China. E-mail address: buhm2004@163.com (H. Bu).
}

isotopic composition $\left({ }^{87} \mathrm{Sr} /{ }^{86} \mathrm{Sr}\right)$ from Canadian rivers in general has a high value of $\sim 0.711$ (Wadleigh et al., 1985). The global average river water value for the strontium isotope ratios $\left({ }^{87} \mathrm{Sr} /{ }^{86} \mathrm{Sr}\right)$ is 0.7119 (Palmer and Edmond, 1989, 1992).

The ${ }^{87} \mathrm{Sr} /{ }^{86} \mathrm{Sr}$ ratio in natural waters can also reflect the contributions made by various dissolved minerals (Clow et al., 1997). Strontium in river water is derived from two sources, the dissolved minerals in the river basin and atmospheric deposition following evaporation of seawater (Faure, 1986; Bain and Bacon, 1994; Aubert et al., 2002). Therefore, the ratio of ${ }^{87} \mathrm{Sr} /{ }^{86} \mathrm{Sr}$ reflects the contribution of two sources, bedrock weathering and atmospheric inputs (Capo et al., 1998). These ratios are relatively constant over time, another reason why they can be used to trace the transport of $\mathrm{Sr}$ through the ecosystem (Graustein, 1989; Bailey et al., 1996). When considered in conjunction with river water chemistry, the $\mathrm{Sr}$ isotopes provide a powerful tool for distinguishing among solute sources in rivers.

Strontium derived from the weathering of bedrock, such as Phanerozoic limestone and dolomite, has a relatively low ${ }^{87} \mathrm{Sr} /{ }^{86} \mathrm{Sr}$ ratio ( 0.707-0.709; Burke et al., 1982). In contrast, the silicate ratio of dust ranges from 0.7109 to 0.7112 , while the ${ }^{87} \mathrm{Sr} /{ }^{86} \mathrm{Sr}$ of parent 
alluvial sediment is relatively high, i.e. 0.7165 (Capo and Chadwick, 1999). Precambrian granitic bedrock derived from felsic rocks generally has high ${ }^{87} \mathrm{Sr} /{ }^{86} \mathrm{Sr}$ values $(>0.71)$. In addition, strontium from current seawater has a fairly constant ${ }^{87} \mathrm{Sr} /{ }^{86} \mathrm{Sr}$ ratio of 0.70916 (Beck et al., 2013). Due to these differentiations in ratios, apportioning the contributions of $\mathrm{Sr}$ from various sources to rivers could be calculated by using ${ }^{87} \mathrm{Sr} /{ }^{86} \mathrm{Sr}$ ratios.

Previous studies have demonstrated the usefulness of the $\mathrm{Sr}$ isotope technique in tracing the geochemical cycling processes of river water (Graustein and Armstrong, 1983; Bain and Bacon, 1994; Capo et al., 1998; Shand et al., 2009). By using ${ }^{87} \mathrm{Sr} /{ }^{86} \mathrm{Sr}$ ratios, Graustein and Armstrong (1983) traced the sources of strontium in natural waters, vegetation, and soil taken from watersheds in the Sangre de Cristo Mountains of New Mexico, and found that more than $75 \%$ of the strontium in the vegetation was derived from atmospheric sources, and less than $25 \%$ from weathering of the underlying bedrock. The ${ }^{87} \mathrm{Sr} /{ }^{86} \mathrm{Sr}$ ratio of rainwater, stream water, soils, and rocks were determined by Bain and Bacon (1994) to determine mineral weathering, and the origin of the solutes in the stream water in two Scottish catchments. Additionally, a number of case studies also highlighted that $\mathrm{Sr}$ isotopes represented a powerful tool in determining weathering processes and quantifying end-member mixing processes when combined with other hydrochemical data (Shand et al., 2009).

Our study examined the geochemistry and sources of $\mathrm{Sr}$ in a minimally disturbed watershed of the South Qinling Mountains (China). We investigated the concentrations of dissolved $\mathrm{Sr}$ and ${ }^{87} \mathrm{Sr} /{ }^{86} \mathrm{Sr}$ ratios of rainwater, forest soil water, and river water in a natural forest river system of the Jinshui River basin in subtropical area of central China. Based on major ion chemistry, Sr concentrations, and ${ }^{87} \mathrm{Sr} /{ }^{86} \mathrm{Sr}$ ratios in different water types, this study attempts to reveal the characteristics of dissolved $\mathrm{Sr}$ and major ions, to find the evolution of ${ }^{87} \mathrm{Sr} /{ }^{86} \mathrm{Sr}$ in different water types, and to determine the contributions of $\mathrm{Sr}$ from atmospheric and weathering end-members in river water of the river basin.

\section{Materials and methods}

\subsection{Study area}

The forest-river water system is entirely located within the Jinshui River basin (730 $\mathrm{km}^{2}$ area) in the South Qinling Mountains, China (Fig. 1). The Jinshui River $\left(33^{\circ} 16^{\prime}-33^{\circ} 45^{\prime} \mathrm{N}\right.$, $107^{\circ} 40^{\prime}-108^{\circ} 10^{\prime} \mathrm{E}$ ) is a tributary of the Han River in the upper Yangtse River. It has a total length of $87 \mathrm{~km}$ and originates from the Foping National Nature Reserve at about $1500 \mathrm{~m}$ above sea-level, a conservation area for Qinling giant pandas, and finally discharges into the Han River at about $430 \mathrm{~m}$ sea-level.

The river basin has a humid monsoonal climate zone (Bu et al., $2010,2015)$. The annual average air temperature in the basin is approximately $11.5^{\circ} \mathrm{C}$, while the highest is $21.9{ }^{\circ} \mathrm{C}$ in summer and the lowest $-0.3^{\circ} \mathrm{C}$ in winter. The rainfall varies between 924 and $1240 \mathrm{~mm}$ year $^{-1}$, and most of the rainfall occurs from June to August. The watershed is a typical mountainous catchment in the South Qinling Mts. of China. Forest and shrub lands, are the major land use types in the river basin covering $96.4 \%$ of the drainage area, with agricultural land only accounting for $2.2 \%$. Additionally, $51.4 \%$ of total human population and $94.1 \%$ of the agricultural lands (principally crops) in the catchment are distributed in the lower reaches of the river, especially in Jinshui Town (Fig. 1). There is no industrial activity.

The Qinling Mountains were formed mainly during the early Mesozoic Orogeny when the Yangtze Block of South China collided with North China (Mattauer et al., 1985). The Jinshui River basin was formed the hills by movements of Yanshan Mountains uplifting and Himalayan Mountains rising in China's tectono-geomorphic types. The rock of the upper river basin is mainly composed of felsic and mafic granulites, granitoids, gneissic granite, metamorphic schist, limestone, shale, conglomerate, and sandstone (Zhai et al., 1998; Xu et al., 2011). In the lower reaches of the river, the low mountain areas are mainly sandstone, shale, conglomerate, red clay, and gravel accumulated by river terraces and underground portion of terraces. The soil is vertically distributed from the high to low elevations, including dark brown, brown, yellow brown, brown, and paddy soils.

\subsection{Sampling and analyses}

Rainwater, river water, and water from forest soil were collected in May 2012 under base flow conditions to characterize the $\mathrm{Sr}$ isotopic composition (Fig. 1). Rainwater (P1, P2, and P3) and water from the forest soil (T1 and T2) were sampled at an elevation above $1100 \mathrm{~m}$ in the source area of the Jinshui River. Rainwater was sampled in open field. Water from forest soil was collected from two pairs of suction lysimeters at depths from 20 to $30 \mathrm{~cm}$ in the oak forest zone. River water samples (S1-S11) were collected from the source area to the mouth of the Jinshui River. Three river water samples ( $\mathrm{H} 1, \mathrm{H} 2$, and $\mathrm{H} 3)$ were also collected in the confluence with the Han River. All water samples were filtered through MFMillipore membrane filters $(0.45 \mu \mathrm{m}$ pore size and $47 \mathrm{~mm}$ diameter, USA). A part of each filtered sample was acidified with highpurity nitric acid and stored in pre-rinsed polyethylene bottles for cation analysis. Filtrate without acidification was also stored for anion analysis.

Cations $\left(\mathrm{Sr}^{2+}, \mathrm{Ca}^{2+}, \mathrm{Mg}^{2+}, \mathrm{Ba}^{2+}, \mathrm{K}^{+}\right.$, and $\left.\mathrm{Na}^{+}\right)$were determined by inductively coupled plasma optical emission spectrometry (ICPOES) (5300 DV, PerkinElmer), and anions $\left(\mathrm{SO}_{4}^{2-}, \mathrm{Cl}^{-}\right.$, and $\mathrm{NO}_{3}^{-}$) were determined by ion chromatography (ICS-90, Dionex) (Institute of Geographic Sciences and Natural Resources Research, Chinese Academy of Sciences, Beijing). Detection limits were $<0.1 \mu \mathrm{g} \mathrm{L}^{-1}$ for $\mathrm{Ca}^{2+}, \mathrm{Mg}^{2+}, \mathrm{Ba}^{2+}$, and $\mathrm{Sr}^{2+}$ and $0.1-1 \mu \mathrm{g} \mathrm{L}^{-1}$ for $\mathrm{Na}^{+}$ and $\mathrm{K}^{+}$. Anions of $\mathrm{HCO}_{3}^{-}$were determined using titration methods (NEPB, 2002). The electrical conductivity (EC), total dissolved solid concentrations (TDS), and $\mathrm{pH}$ in water samples were determined in situ by using conductometer (YSI Incorporated, Yellow Springs, $\mathrm{OH}$, USA).

Samples were pretreated prior to measurement for $\mathrm{Sr}$ isotopes using the water $\mathrm{Sr}$ isotopic analysis method (Li et al., 2012). Approximately 5-8 g of water samples were weighed into Savillex $15 \mathrm{~mL}$ Teflon-PFA vials. The samples were dried on a hotplate at $100{ }^{\circ} \mathrm{C}$. Then, the samples were re-dissolved using $1.1 \mathrm{~mL}$ of $2.5 \mathrm{~mol} \mathrm{~L}^{-1} \mathrm{HCl}$. The sample solution was cooled to room temperature for $1 \mathrm{~h}$ before centrifugation for $8 \mathrm{~min}$ at $5000 \mathrm{rpm}$. Then, the supernatant was collected from centrifuge tubes and dried on a hotplate. Next, the samples were re-dissolved with $1.0 \mathrm{~mL}$ of $2.5 \mathrm{~mol} \mathrm{~L}^{-1} \mathrm{HCl}$. Then, the sample solution was loaded onto the preconditioned resin column with $2 \mathrm{~mL}$ of AG50W $\times 12(200-400$ mesh) for the separation of $\mathrm{Sr}$ from the sample matrix. After rinsing four times with $0.5 \mathrm{~mL}$ of $2.5 \mathrm{~mol} \mathrm{~L}^{-1} \mathrm{HCl}$, the column was washed with $7 \mathrm{~mL}$ of $5 \mathrm{~mol} \mathrm{~L}^{-1} \mathrm{HCl}$. Afterwards, the Sr fraction was stripped with $3.5 \mathrm{~mL}$ of $5 \mathrm{~mol} \mathrm{~L}^{-1} \mathrm{HCl}$. Finally, the $\mathrm{Sr}$ fraction was evaporated to dryness for analysis by thermal ionization mass spectrometry (TIMS). The blank for this procedure was lower than $300 \mathrm{pg}$ for Sr.

The $\mathrm{Sr}$ isotopic measurements were performed on a Finnigan MAT $262^{\circledR}$ multi-collector mass spectrometer (Institute of Geology and Geophysics, Chinese Academy of Sciences, Beijing). A double Re filament configuration was used to determine $\mathrm{Sr}$. Sr isotopic data was acquired in the static collection mode. The mass fractionation of $\mathrm{Sr}$ was corrected using the exponential law with ${ }^{88} \mathrm{Sr} /{ }^{86} \mathrm{Sr}=8.375209$. An international standard sample NBS-987 


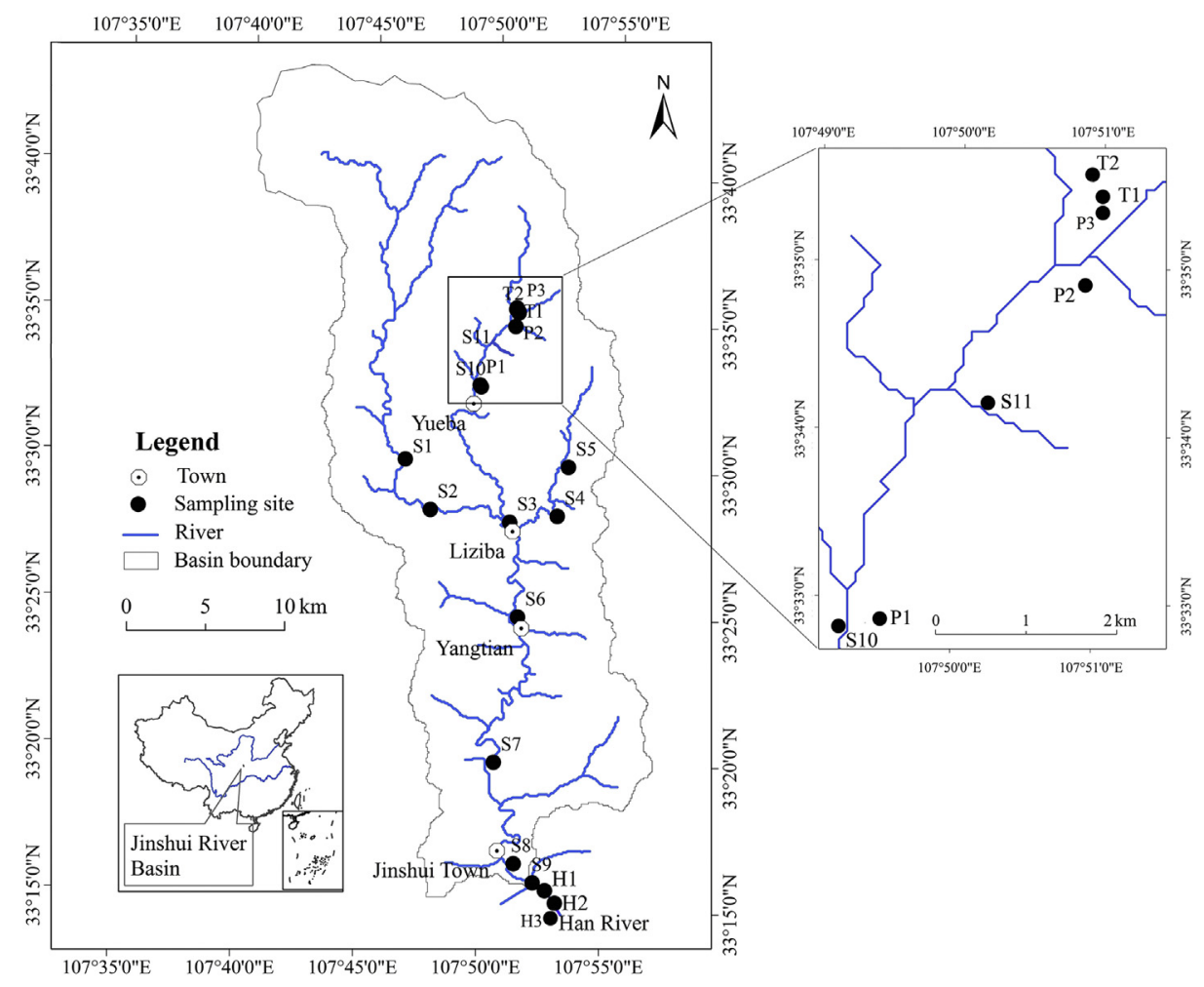

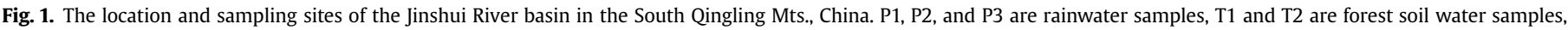
$\mathrm{S} 1-\mathrm{S} 11$ are river water samples in the Jinshi River, and H1-H3 are river water samples in the Han River, respectively.

was employed to evaluate instrument stability during the period of data collection. The mass spectrometer yielded a value of $0.710258 \pm 0.000010(2 \sigma, \mathrm{n}=4)$ for the NBS-987 Sr metal standard during the measurement period, in good agreement with the reported values (Li et al., 2012). The ${ }^{87} \mathrm{Sr} /{ }^{86} \mathrm{Sr}$ ratios of samples were precise to within $0.000012(2 \sigma)$.

\subsection{Statistical analyses}

The One-way ANOVA with Nonparametric Dunnett's $C$ test was performed to analyze the differences in $\mathrm{Sr}$ concentrations and ${ }^{87} \mathrm{Sr} /{ }^{86} \mathrm{Sr}$ ratios of different water types, since $\mathrm{Sr}$ concentrations and ${ }^{87} \mathrm{Sr} /{ }^{86} \mathrm{Sr}$ ratios were abnormally distributed and had unequalvariance (Bu et al., 2010, 2015). Correlation analysis was applied to explore correlations between dissolved $\mathrm{Sr}$ and major ions, which were expressed by Pearson's correlation coefficients at the $p<0.01$ and $p<0.05$ levels (two-tailed). Linear regression, based on $p$ value, was used to simulate the correlations between dissolved $\mathrm{Sr}$ and major ions to explain their characteristics in waters. All statistical analyses were performed using SPSS 13.0.

The contributions from three sources to a mixture were quantified using a three-source mixing model (Phillips and Gregg, 2001). For a three-end-member mixture, the three-source mixing model could be formulated from the following mass balance equations:

$\left\{\begin{array}{l}f_{A} \bar{\delta}_{A}+f_{B} \bar{\delta}_{B}+f_{C} \bar{\delta}_{C}=\bar{\delta}_{M} \\ f_{A} \bar{\lambda}_{A}+f_{B} \bar{\lambda}_{B}+f_{C} \bar{\lambda}_{C}=\bar{\lambda}_{M} \\ f_{A}+f_{B}+f_{C}=1\end{array}\right.$

where $\bar{\delta}$ and $\bar{\lambda}$ represent mean isotopic compositions for two elements, the subscripts refer to the three sources $A, B$, and $C$, and the mixture $M$, and $f_{A}, f_{B}$, and $f_{C}$ are the proportions of $A, B$, and $C$ in $M$.

\section{Results}

\subsection{Dissolved Sr concentrations in the river water system}

The $\mathrm{Sr}$ concentrations were significantly different between each water type in the Jinshui River basin $\left(F_{3,18}=20.278, p<0.001\right)$ (Table 1). The rainwater collected in open field had the lowest $\mathrm{Sr}$ concentration ranging from 37 to $51 \mu \mathrm{g} \mathrm{L}^{-1}$, with mean value of $42 \mu \mathrm{g} \mathrm{L}^{-1}(\mathrm{n}=3)$. The $\mathrm{Sr}$ concentrations in the Jinshui River ranged from 44 to $120 \mu \mathrm{g} \mathrm{L}^{-1}$ with a mean value of $77 \mu \mathrm{g} \mathrm{L}^{-1}(\mathrm{n}=11)$, which is very close to the global river average of $78 \mu \mathrm{g} \mathrm{L}^{-1}$ (Palmer and Edmond, 1992). Concentrations were higher in river water from the Han River, ranging from 124 to $206 \mu \mathrm{g} \mathrm{L}^{-1}$ with a mean of $172 \mu \mathrm{g} \mathrm{L}^{-1}(\mathrm{n}=3)$. This is close to the mean $\mathrm{Sr}$ concentration of the Han River basin $\left(179.6 \mu \mathrm{g} \mathrm{L}^{-1}\right)$ studied by Xu et al. (2011). Water from forest soil had the highest Sr concentration of $234 \mu \mathrm{g} \mathrm{L}^{-1}$, and mean value of $189 \mu \mathrm{g} \mathrm{L}^{-1}(\mathrm{n}=2)$, while its lowest value is $145 \mu \mathrm{g} \mathrm{L}^{-1}$.

\section{2. ${ }^{87} \mathrm{Sr} /{ }^{86} \mathrm{Sr}$ ratios in the river water system}

There were statistical differences in the ${ }^{87} \mathrm{Sr} /{ }^{86} \mathrm{Sr}$ ratios in the different water types $\left(\mathrm{F}_{3,18}=23.010, \mathrm{p}<0.001\right)$ (Table 1$)$. The $\mathrm{Sr}$ isotope ratios of river water in the Jinshui River ranged from 0.71070 to 0.71137 , with a mean value of $0.71116(n=11)$. The river water in the confluence of the Jinshui River and the Han River had the least non-radiogenic $\mathrm{Sr}$ isotope ratio of all the samples, i.e. $0.71088 \pm 0.00018$ (mean \pm S.D., $\mathrm{n}=3$ ), with a range of $0.71067-0.71102$. The average isotope ratio of rainwater was $0.71116 \pm 0.00011(n=3)$. Water from forest soil was the most radiogenic compared with the other samples, which the mean ${ }^{87} \mathrm{Sr} /{ }^{86} \mathrm{Sr}$ ratio is $0.71213(\mathrm{n}=2)$, ranging from 0.71209 to 0.71216 . 
Table 1

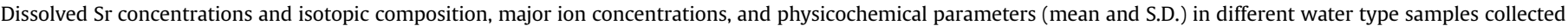
during May 2012 in the Jinshui River basin of the South Qingling Mts., China.

\begin{tabular}{|c|c|c|c|c|c|c|c|c|}
\hline \multirow[t]{2}{*}{ Parameter } & \multicolumn{2}{|c|}{ River water $(\mathrm{n}=11)$} & \multicolumn{2}{|c|}{ Han river water $(\mathrm{n}=3)$} & \multicolumn{2}{|c|}{ Rainwater $(\mathrm{n}=3)$} & \multicolumn{2}{|c|}{ Forest soil water $(\mathrm{n}=2)$} \\
\hline & Mean & S.D. & Mean & S.D. & Mean & S.D. & Mean & S.D. \\
\hline $\operatorname{Sr}\left(\mu \mathrm{g} \mathrm{L}^{-1}\right)$ & 77 & 27 & 172 & 43 & 42 & 8 & 189 & 63 \\
\hline${ }^{87} \mathrm{Sr} /{ }^{86} \mathrm{Sr}$ & 0.711156 & 0.000230 & 0.710876 & 0.000181 & 0.711159 & 0.000112 & 0.712129 & 0.000049 \\
\hline $\mathrm{Ca}\left(\mathrm{mg} \mathrm{L}^{-1}\right)$ & 21.19 & 8.36 & 44.48 & 8.58 & 10.28 & 3.28 & 37.41 & 9.17 \\
\hline $\operatorname{Mg}\left(\mathrm{mg} \mathrm{L}^{-1}\right)$ & 3.43 & 1.59 & 8.53 & 2.52 & 1.26 & 0.77 & 9.14 & 3.90 \\
\hline $\mathrm{Ba}\left(\mathrm{mg} \mathrm{L}^{-1}\right)$ & 0.03 & 0.01 & 0.04 & 0.01 & 0.03 & 0.01 & 0.10 & 0.02 \\
\hline $\mathrm{K}\left(\mathrm{mg} \mathrm{L}^{-1}\right)$ & 1.61 & 0.42 & 1.80 & 0.38 & 4.50 & 3.46 & 17.92 & 0.89 \\
\hline $\mathrm{Na}\left(\mathrm{mg} \mathrm{L}^{-1}\right)$ & 3.36 & 0.81 & 10.13 & 0.30 & 1.11 & 0.63 & 1.17 & 0.16 \\
\hline $\mathrm{SO}_{4}^{2-}\left(\mathrm{mg} \mathrm{L}^{-1}\right)$ & 13.5 & 1.9 & 24.7 & 5.3 & 14.7 & 9.5 & 34.5 & 28.3 \\
\hline $\mathrm{Cl}^{-}\left(\mathrm{mg} \mathrm{L}^{-1}\right)$ & 1.0 & 0.2 & 6.4 & 3.1 & 1.9 & 1.6 & 6.4 & 3.7 \\
\hline $\mathrm{NO}_{3}^{-}\left(\mathrm{mg} \mathrm{L}^{-1}\right)$ & 4.4 & 1.5 & 9.5 & 2.0 & 0.8 & 0.1 & 45.3 & 24.1 \\
\hline $\mathrm{HCO}_{3}^{-}\left(\mathrm{mg} \mathrm{L}^{-1}\right)$ & 102.6 & 23.4 & 138.9 & 22.7 & 71.9 & 11.8 & 93.9 & 22.3 \\
\hline $\mathrm{pH}$ & 7.7 & 0.5 & 7.5 & 0.2 & 7.0 & 0.3 & 7.0 & 0.3 \\
\hline $\mathrm{EC}\left(\mu \mathrm{S} \mathrm{cm}^{-1}\right)$ & 150.1 & 54.8 & 345.3 & 86.8 & 81.9 & 42.5 & 207.4 & 149.3 \\
\hline TDS $\left(\mathrm{mg} \mathrm{L}^{-1}\right)$ & 76.9 & 25.8 & 164.9 & 42.1 & 44.0 & 21.6 & 151.4 & 58.1 \\
\hline
\end{tabular}

\subsection{Correlations between dissolved Sr and major ions and physicochemical parameters}

Dissolved $\mathrm{Sr}$ in the river water system was significantly correlated with the ions, $\mathrm{Ca}^{2+}, \mathrm{Mg}^{2+}, \mathrm{Ba}^{2+}, \mathrm{SO}_{4}^{2-}, \mathrm{Cl}^{-}, \mathrm{NO}_{3}^{-}$as well as $\mathrm{EC}$, and TDS $(p<0.01$; Table 2$)$ in correlation analysis. It was significantly correlated with $\mathrm{K}^{+}, \mathrm{Na}^{+}$, and $\mathrm{HCO}_{3}^{-}$at $p<0.05$ level (Table 2). Dissolved $\mathrm{Sr}$ was also strongly correlated with $\mathrm{Ca}\left(\mathrm{r}^{2}=0.883\right.$, $\mathrm{p}<0.001), \mathrm{Mg}\left(\mathrm{r}^{2}=0.963, \mathrm{p}<0.001\right), \mathrm{EC}\left(\mathrm{r}^{2}=0.774, \mathrm{p}<0.001\right)$, and TDS $\left(r^{2}=0.950, p<0.001\right)$ in a regression analysis (Fig. 2$)$.

3.4. Correlations between ${ }^{87} \mathrm{Sr} /{ }^{86} \mathrm{Sr}$ and $\mathrm{Ca} / \mathrm{Na}$ ratios, $\mathrm{Ca} / \mathrm{K}$ ratios, and $1000 / \mathrm{Sr}$ in the river water system

The strontium isotope rations, ${ }^{87} \mathrm{Sr} /{ }^{86} \mathrm{Sr}$ were plotted against $\mathrm{Ca} /$ $\mathrm{Na}$ ratios (Fig. 3a) and $\mathrm{Ca} / \mathrm{K}$ ratios (Fig. 3b). There was separation between all water sample groups. Forest soil water with the highest ${ }^{87} \mathrm{Sr} /{ }^{86} \mathrm{Sr}$ ratios also had the highest $\mathrm{Ca} / \mathrm{Na}$ ratios and the lowest $\mathrm{Ca} /$ $\mathrm{K}$ ratios. Rainwater had a much lower ${ }^{87} \mathrm{Sr} /{ }^{86} \mathrm{Sr}$ ratio with $\mathrm{Ca} / \mathrm{Na}$ ratios $>8$ and $\mathrm{Ca} / \mathrm{K}$ ratios lower than 4 . The Han River water samples with the highest $\mathrm{Ca} / \mathrm{K}$ ratios and the lowest ${ }^{87} \mathrm{Sr} /{ }^{86} \mathrm{Sr}$ ratios and $\mathrm{Ca} /$ $\mathrm{Na}$ ratios. The Jinshui River water had $\mathrm{Ca} / \mathrm{Na}$ ratios between 4 and 8 , but relatively high $\mathrm{Ca} / \mathrm{K}$ ratios ranging from 9 to 16 .

The ${ }^{87} \mathrm{Sr} /{ }^{86} \mathrm{Sr}$ ratios were plotted against the reciprocal of the $\mathrm{Sr}$ concentrations $(1000 / \mathrm{Sr})$ for all water samples in river water system and there was a high level of separation between the sample types (Fig. 4a). Forest soil water had much higher ${ }^{87} \mathrm{Sr} /{ }^{86} \mathrm{Sr}$ ratios and $\mathrm{Sr}$ concentrations than the other water samples. The Han River water had lower ${ }^{87} \mathrm{Sr} /{ }^{86} \mathrm{Sr}$ ratios but higher $\mathrm{Sr}$ concentrations, while rainwater had lower ${ }^{87} \mathrm{Sr} /{ }^{86} \mathrm{Sr}$ ratios and $\mathrm{Sr}$ concentrations. The Jinshui River water samples fell between the Han River waters and rainwaters. The ${ }^{87} \mathrm{Sr} /{ }^{86} \mathrm{Sr}$ ratio vs. $1000 / \mathrm{Sr}$ was also plotted as mean \pm 2 S.E. values for the different water types also showing the three end-members of river water: Atmospheric inputs, carbonate and silicate weathering (Fig. 4b).

\subsection{Source contributions of the three end-members in the river water system}

According to Eq. (1), the mean proportion of each end-member in the Jinshui River water was calculated based on the concentrations and isotope ratios of $\mathrm{Sr}$ using the equations:

$$
\left\{\begin{array}{l}
f_{a}\left({ }^{87} S r /{ }^{86} S r\right)_{a}+f_{c}\left({ }^{87} S r /{ }^{86} S r\right)_{c}+f_{S}\left({ }^{87} S r /{ }^{86} S r\right)_{s}=\left({ }^{87} S r /{ }^{86} S r\right)_{R} \\
f_{a}(S r)_{a}+f_{c}(S r)_{c}+f_{s}(S r)_{s}=(S r)_{R} \\
f_{a}+f_{c}+f_{S}=1
\end{array}\right.
$$

where $\left({ }^{87} \mathrm{Sr} /{ }^{86} \mathrm{Sr}\right)$ is the mean ${ }^{87} \mathrm{Sr} /{ }^{86} \mathrm{Sr}$ ratio and $(\mathrm{Sr})$ is the mean concentration; the subscripts of $a, c$, and $s$ refer to the three sources

Table 2

Correlation coefficients among dissolved $\mathrm{Sr}$ and major ion concentrations, and physicochemical parameters.

\begin{tabular}{|c|c|c|c|c|c|c|c|c|c|c|c|c|c|}
\hline & $\mathrm{Sr}$ & $\mathrm{Ca}$ & $\mathrm{Mg}$ & $\mathrm{Ba}$ & K & $\mathrm{Na}$ & $\mathrm{SO}_{4}^{2-}$ & $\mathrm{Cl}^{-}$ & $\mathrm{NO}_{3}^{-}$ & $\mathrm{HCO}_{3}^{-}$ & $\mathrm{pH}$ & EC & TDS \\
\hline $\mathrm{Sr}$ & 1 & & & & & & & & & & & & \\
\hline $\mathrm{Ca}$ & $0.940^{* *}$ & 1 & & & & & & & & & & & \\
\hline $\mathrm{Mg}$ & $0.981^{* *}$ & $0.957^{* *}$ & 1 & & & & & & & & & & \\
\hline $\mathrm{Ba}$ & $0.750^{* *}$ & $0.566^{*}$ & $0.728^{*}$ & 1 & & & & & & & & & \\
\hline K & $0.477^{*}$ & 0.274 & 0.444 & $0.873^{* *}$ & 1 & & & & & & & & \\
\hline $\mathrm{Na}$ & $0.516^{*}$ & $0.696^{* *}$ & $0.539^{*}$ & -0.127 & -0.354 & 1 & & & & & & & \\
\hline $\mathrm{SO}_{4}^{2-}$ & $0.800^{* *}$ & $0.690^{* *}$ & $0.818^{* *}$ & $0.699^{* *}$ & $0.539^{*}$ & 0.261 & 1 & & & & & & \\
\hline $\mathrm{Cl}^{-}$ & $0.871^{* *}$ & $0.778^{* *}$ & $0.863^{* *}$ & $0.647^{* *}$ & 0.499* & 0.445 & $0.888^{* *}$ & 1 & & & & & \\
\hline $\mathrm{NO}_{3}^{-}$ & $0.703^{* *}$ & $0.478^{*}$ & $0.674^{* *}$ & $0.897^{* *}$ & $0.809^{* *}$ & -0.127 & $0.770^{* *}$ & $0.670^{* *}$ & 1 & & & & \\
\hline $\mathrm{HCO}_{3}^{-}$ & $0.519^{*}$ & $0.567^{* *}$ & $0.546^{*}$ & 0.110 & -0.177 & $0.641^{* *}$ & 0.387 & $0.478^{*}$ & 0.125 & 1 & & & \\
\hline $\mathrm{pH}$ & 0.003 & 0.248 & 0.049 & -0.263 & -0.393 & 0.338 & -0.227 & -0.294 & -0.348 & -0.003 & 1 & & \\
\hline EC & $0.880^{* *}$ & $0.939^{* *}$ & $0.900^{* *}$ & 0.404 & 0.074 & $0.777^{* *}$ & $0.725^{* *}$ & $0.788^{* *}$ & 0.357 & $0.672^{* *}$ & 0.194 & 1 & \\
\hline TDS & $0.975^{* *}$ & $0.970^{* *}$ & $0.983^{* *}$ & $0.645^{* *}$ & 0.358 & $0.624^{* *}$ & $0.805^{* *}$ & $0.866^{* *}$ & $0.585^{* *}$ & $0.596^{* *}$ & 0.078 & $0.949^{* *}$ & 1 \\
\hline
\end{tabular}

** Correlation is significant at the 0.01 level (2-tailed).

* Correlation is significant at the 0.05 level (2-tailed). 

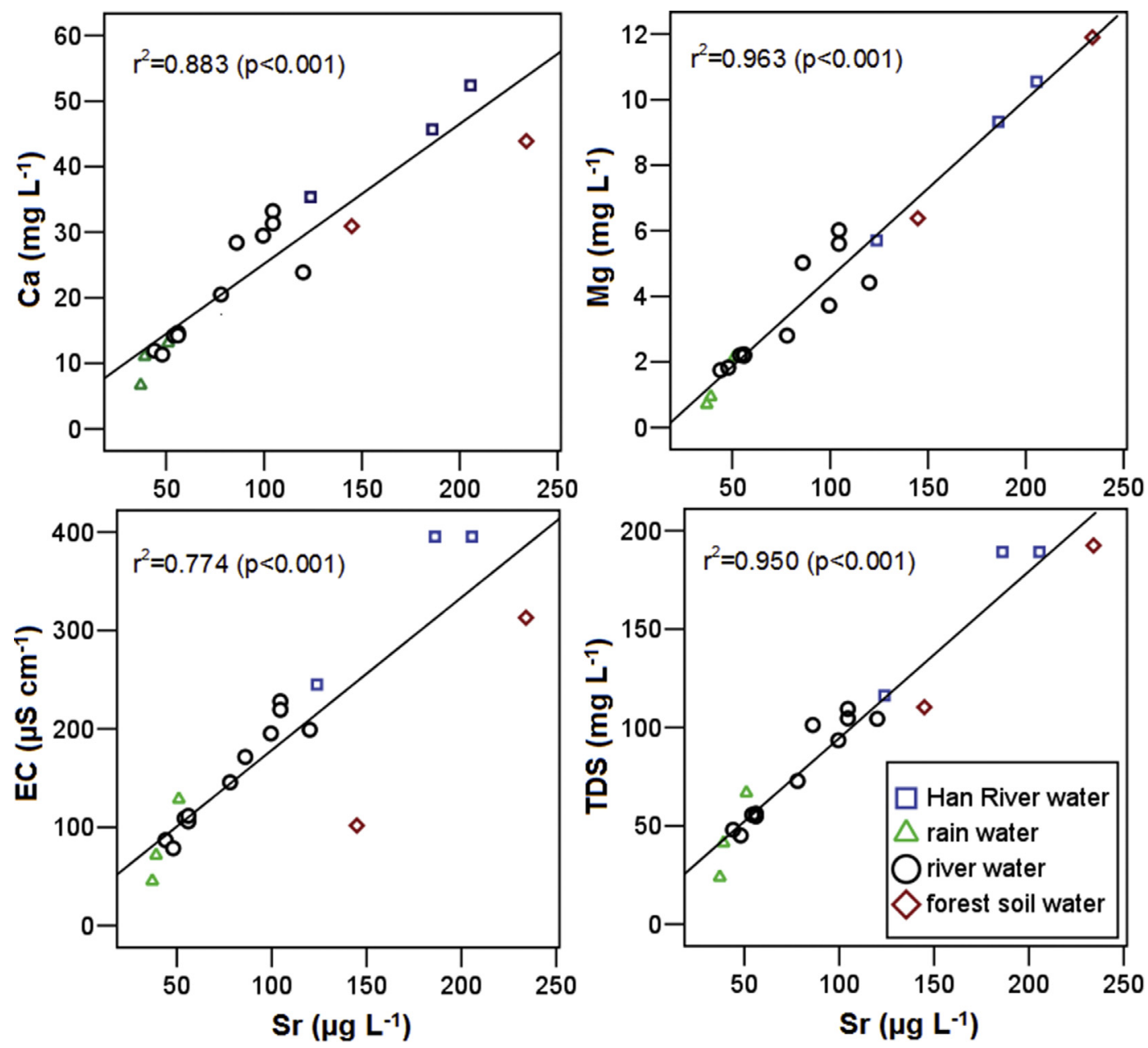

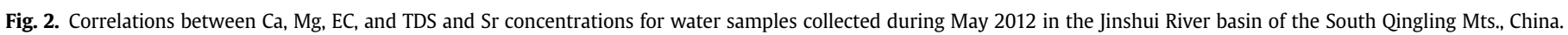
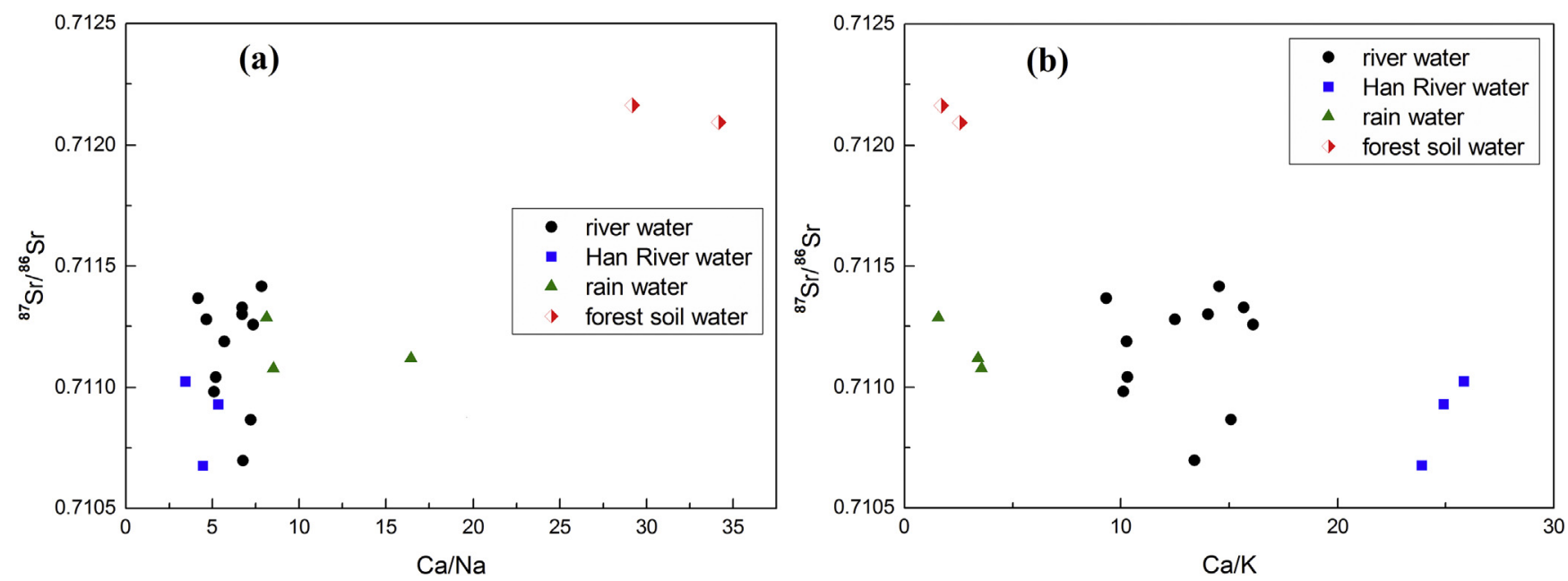

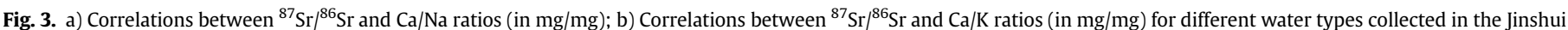
River basin of the South Qinling Mts., China.

from rain water, carbonate rock weathering, and silicate rock weathering, and $R$ refers to river water as the mixture; $f_{a}, f_{c}$, and $f_{s}$ are the proportions of $a, c$, and $s$ in $R$.

Using the Eq. (2), the proportion of atmospheric input endmember was $74 \pm 8 \%$ (mean \pm S.E.), and carbonate and silicate rock weathering respectively contributed $20 \pm 10 \%$ and $6 \pm 7 \%$ to $\mathrm{Sr}$ concentrations of the Jinshui River water. 

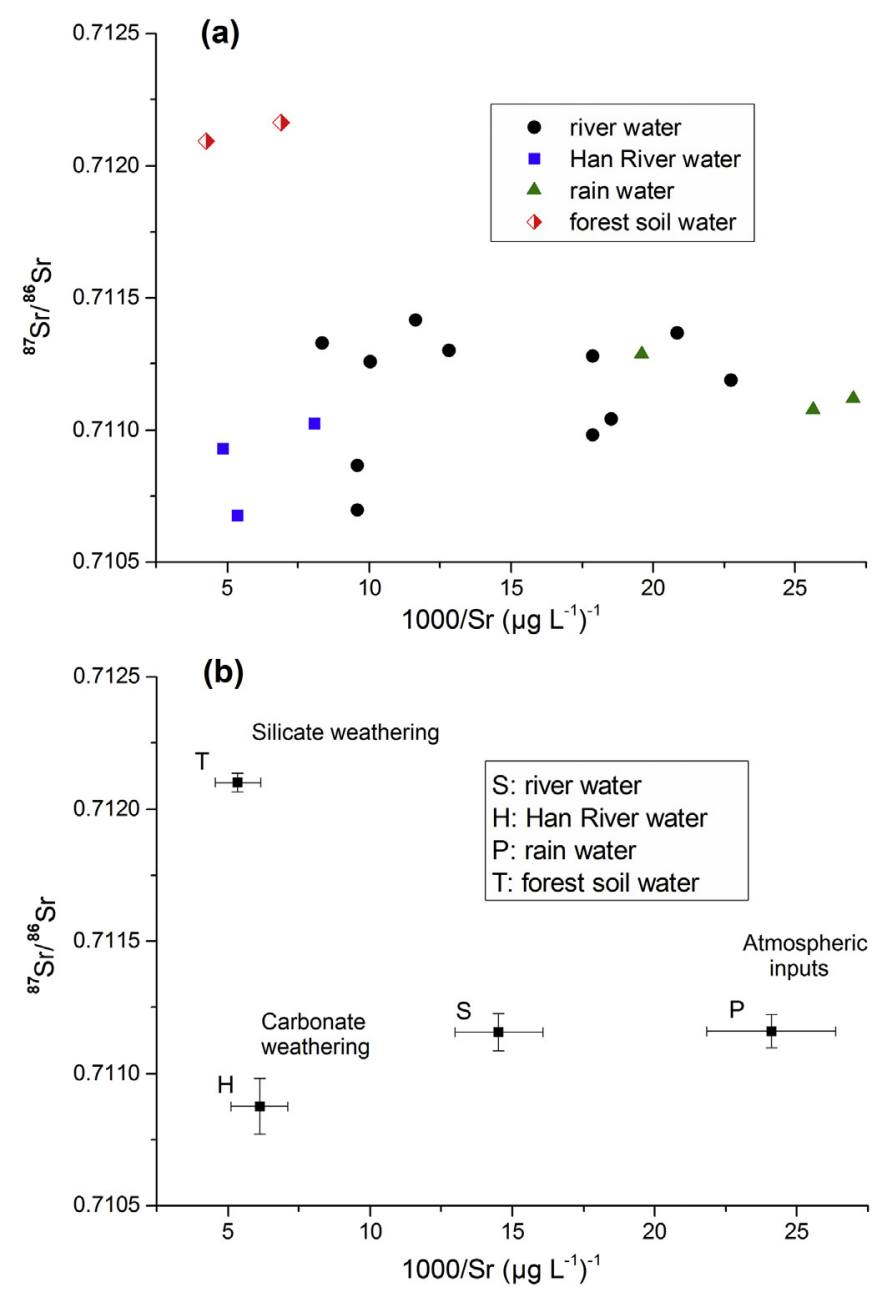

Fig. 4. Correlations between the ${ }^{87} \mathrm{Sr} /{ }^{86} \mathrm{Sr}$ ratios and $1000 / \mathrm{Sr}$ concentrations ( $\mu \mathrm{g} \mathrm{L}{ }^{-1}$ ) for the forest river water system collected in the Jinshui River basin of the South Qinling Mts., China. a) Values for all data to show their positions; b) mean \pm 2 S.E. for different water types to show the end-members.

\section{Discussion}

4.1. Characteristics of dissolved Sr and major ions in the river water system

In our study, dissolved $\mathrm{Ca}$ and $\mathrm{HCO}_{3}^{-}$concentrations accounted for over $75 \%$ of the molar concentrations of all major ions in all water types (Table 1), except forest soil water. Other studies have shown that carbonate in a river water system can be dominated by rock weathering, e.g. Ganga headwater basins, India (Tripathy et al., 2010). Additionally, in our study $\mathrm{Ca}^{2+}+\mathrm{Mg}^{2+}$ concentrations dominated about $80 \%$ of the cations in the Jinshui River water and the Han River water, showing that the natural sources of isotopic composition of $\mathrm{Sr}$ for river water in the forested watershed were mainly from atmospheric inputs and carbonate weathering inputs (Bailey et al., 1996). The results confirmed the findings from Xu and his coworkers who showed that the Han River is a typical carbonate-dominated river (Xu et al., 2011).

The dissolved $\mathrm{Sr}$ in different water types showed significant positive correlations with major ions and physicochemical parameters during the sampling period (Table 2). These findings indicated their similar geochemical and biological processes in waters (Aubert et al., 2002) and common origins (Shand et al.,
2009), which control the weathering of Sr. Moreover, the dissolved $\mathrm{Sr}$ firmly linked with $\mathrm{NO}_{3}^{-}$in the river water system, which may be partly induced by consumption of plants or algae during the sampling season (Bu et al., 2015).

The dissolved Sr strongly covaried with $\mathrm{Ca}, \mathrm{Mg}, \mathrm{EC}$, and TDS in the river water system. The linear correlation between Sr concentrations and both $\mathrm{Ca}$ and $\mathrm{Mg}$ in all water types suggests that $\mathrm{Sr}$ can be used as an analogue for tracing sources and cycling processes of dissolved Ca and Mg (Capo et al., 1998; Aubert et al., 2002). This correlation also indicates that rock weathering is an important source for dissolved Sr (Wu et al., 2009) in different water types in the Jinshui River basin. Dissolved Sr has a slightly higher correlation with $\mathrm{Mg}$ than with $\mathrm{Ca}$. This suggests that carbonate from limestone is not the major contributor to dissolved $\mathrm{Sr}$ in the river water system, but shale and/or sandstone are more important ones. This is similar to the findings of Löfvendahl et al. (1990). The dissolved Sr concentrations also correlated with EC and TDS in all water samples, suggesting that the dissolved $\mathrm{Sr}$ in the river water system was controlled by similar hydrochemical processes to EC and TDS, such as colloid destabilization or sedimentary inputs (Bu et al., 2015). Thus, the correlations between $\mathrm{Sr}$ and major ions and physicochemical parameters, have given insights into hydrological and geochemical processes, as well as deducing sources of $\mathrm{Sr}$ (Shand et al., 2009).

\subsection{Evolution of ${ }^{87} \mathrm{Sr} /{ }^{86} \mathrm{Sr}$ in the river water system}

Our study showed that the ${ }^{87} \mathrm{Sr} /{ }^{86} \mathrm{Sr}$ ratios in rainwater samples were significantly different to other water types, consistent with previous studies (Aubert et al., 2002). Clearly, rainwater, as the beginning in a river water system (Clow et al., 1997), contributes to river systems, and therefore isotopic composition of rainwater is a contributor (Bailey et al., 1996). The average isotope ratio of the Jinshui River water was generally similar to that of rainwater, suggesting the importance of wet deposition. This has also been demonstrated by Gosz and Moore (1989) and Aubert et al. (2002).

Overall, the mean value of $\mathrm{Sr}$ isotope ratios in the Jinshui River water was slightly lower than the global river average of 0.7119 (Palmer and Edmond, 1989, 1992) and higher than that of global seawater $\left({ }^{87} \mathrm{Sr} /{ }^{86} \mathrm{Sr}=0.70916\right.$; Beck et al., 2013), but close to the $\mathrm{Sr}$ from Canadian rivers with value of $\sim 0.711$ (Wadleigh et al., 1985), reflecting weathering and erosion of continents which are influenced by sea level and climatic change (Palmer and Edmond, 1989; Capo et al., 1998).

In water cycle processes in a forested watershed, the chemistry of river water is the result of a combination of processes that occur in the atmosphere, vegetation, soil, and aquatic environments. Precipitation represents the beginning of the hydrologic cycle (Clow et al., 1997), thus, the rainwater data in this study are a useful chemical reference point to describe the effects of geochemical processes on natural waters in the forested watershed. Our rainwater samples had relatively low ${ }^{87} \mathrm{Sr} /{ }^{86} \mathrm{Sr}$ and relatively high $\mathrm{Ca} /$ $\mathrm{Na}$ ratios $(>8)$, suggesting that most of the $\mathrm{Sr}$ in rain water was derived from airborne carbonate dust (Åberg, 1995). The higher Ca/ $\mathrm{Na}$ ratios in rainwater also indicate that carbonate minerals in the atmosphere have important influence on the chemistry of rainwater. Forest soil water samples, whose dominant mineral is silicate, were more strongly influenced by granitoids, metamorphic schist, and calcite weathering, as indicated by much higher ${ }^{87} \mathrm{Sr} /{ }^{86} \mathrm{Sr}$ and $\mathrm{Ca} / \mathrm{Na}$ ratios compared to rainwater. Overall, this study showed that the river water $\mathrm{Sr}$ is controlled by the three endmembers: atmospheric inputs, and carbonate and silicate weathering. Based on our analyses, it also appears that the water leached from forest soil was not a dominant input to the Jinshui River water.

The sources of dissolved $\mathrm{Sr}$ in the river water system are further 
distinguished. Analysis of the Sr isotopes, and $\mathrm{Sr}$ and ion concentrations showed that the dissolution of carbonate rocks (like limestone) with low ${ }^{87} \mathrm{Sr} /{ }^{86} \mathrm{Sr}$ ratios $(<0.71)$ made a substantial contribution to the $\mathrm{Sr}$ of the Han River system (Goldstein and Jacobsen, 1987; Xu et al., 2011). Therefore, the Han River water was used to represent the carbonate weathering end-member. Forest soil water had the most radiogenic Sr with high ${ }^{87} \mathrm{Sr} /{ }^{86} \mathrm{Sr}$ ratios, which could be regarded as silicate weathering endmember. Additionally, the rainwater with low concentrations and isotope ratios of $\mathrm{Sr}$ was the atmospheric input end-member in the river water system.

\subsection{Atmospheric and weathering end-members in the river water system}

It is assumed that the $\mathrm{Sr}$ related processes measured in our study are representative of the system in the longer term as the South Qinling Mts. have relatively little human activities or natural disturbances (Pett-Ridge et al., 2009). The ultimate sources of Sr to an undisturbed forested watershed are atmospheric deposition, which includes wet and dry deposition, and weathering of local bedrock minerals (Åberg, 1995; Clow et al., 1997). In the Jinshui River basin, the wet deposition dominated since the river is in a humid monsoon climate zone. The dry deposition is generated through settling of particulates transported by wind. Indeed, our study demonstrated that atmospheric inputs accounted for a substantial proportion $(74 \pm 8 \%$ ) for the river water system in the watershed. Carbonate rock weathering contributed $20 \pm 10 \%$ to the river water, while silicate rock weathering $(6 \pm 7 \%)$ was not a major input to the Jinshui River water.

\section{Conclusions}

This study investigates the dissolved $\mathrm{Sr}$ concentrations and ${ }^{87} \mathrm{Sr} /{ }^{86} \mathrm{Sr}$ ratios of rain water, river water, and water from forest soil in a forest-river water system of the South Qinling Mts., China under base flow conditions. Concentrations and stable isotope ratios of dissolved $\mathrm{Sr}$ differed between water types. The dissolved $\mathrm{Sr}$ concentrations also correlated with $\mathrm{Ca}$ and $\mathrm{Mg}$ concentrations as well as EC, and TDS in the river water system meaning that $\mathrm{Sr}$ concentrations can be a useful proxy to understand processes associated with these parameters. Three end-members of atmospheric inputs, carbonate and silicate weathering are identified to control the $\mathrm{Sr}$ water chemistry in the river water system, and their contributions are $74 \%, 20 \%$, and $6 \%$ to the river water, respectively.

\section{Acknowledgements}

This research was supported by the National Natural Science Foundation of China (Grant No. 41103069) and the China Scholarship Council (No. 201404910228). The research was also supported by the Australian Rivers Institute as they provided facilities for Dr. Hongmei $\mathrm{Bu}$ to complete the manuscript. The authors express sincere gratitude to Baogang Jiang, Xiangmin Sun, Wenjia Wang, Zhenyu Sun, and Fei Liu for their assistance during the fieldwork. The authors also thank two anonymous reviewers for their valuable comments.

\section{References}

Åberg, G., 1995. The use of natural strontium isotopes as tracers in environment studies. Water Air Soil Pollut. 79, 309-322.

Aubert, D., Probst, A., Stille, P., Viville, D., 2002. Evidence of hydrological control of Sr behavior in stream water (Strengbach catchment, Vosges Mountains, France). Appl. Geochem 17, 285-300.

Bailey, S.W., Hornbeck, J.W., Driscoll, C.T., Gaudette, H.E., 1996. Calcium inputs and transport in a base-poor forest ecosystem as interpreted by $\mathrm{Sr}$ isotopes. Water Resour. Res. 32, 707-719.

Bain, D.C., Bacon, J.R., 1994. Strontium isotopes as indicators of mineral weathering in catchments. Catena 22, 201-214.

Beck, A.J., Charette, M.A., Cochran, J.K., Gonneea, M.E., Peucker-Ehrenbrink, B., 2013. Dissolved strontium in the subterranean estuary - implications for the marine strontium isotope budget. Geochim. Cosmochim. Ac 117, 33-52.

Bu, H., Tan, X., Li, S., Zhang, Q., 2010. Temporal and spatial variations of water quality in the Jinshui River, China. Ecotox. Environ. Safe 73, 907-913.

Bu, H., Wang, W., Song, X., Zhang, Q., 2015. Characteristics and source identification of dissolved trace elements in the Jinshui river of the South Qinling Mts., China. Environ. Sci. Pollut. R. 22 (18), 14248-14257.

Burke, W.H., Denison, R.E., Hetherington, E.A., Koepnick, R.B., Nelson, H.F., Otto, J.B., 1982. Variation of seawater ${ }^{87} \mathrm{Sr} /{ }^{86} \mathrm{Sr}$ throughout Phanerozoic time. Geology 10, 516-519.

Capo, R.C., Chadwick, O.A., 1999. Sources of strontium and calcium in desert soil and calcrete. Earth Planet. Sc. Lett. 170, 61-72.

Capo, R.C., Stewart, B.W., Chadwick, O.A., 1998. Strontium isotopes as tracers of ecosystem processes: theory and methods. Geoderma 82, 197-225.

Clow, D.W., Mast, M.A., Bullen, T.D., Turk, J.T., 1997. Strontium 87/strontium 86 as a tracer of mineral weathering reactions and calcium sources in an alpine/subalpine watershed, Loch Vale, Colorado. Water Resour. Res. 33, 1335-1351.

Faure, G., 1986. Principles of Isotope Geology, second ed. Wiley, New York, p. 589.

Goldstein, S.J., Jacobsen, S.B., 1987. The Nd and Sr isotopic systematics of river-water dissolved material: implications for the sources of $\mathrm{Nd}$ and $\mathrm{Sr}$ in seawater. Chem. Geol./Isot. Geosci. 66, 245-272.

Gosz, J.R., Moore, D.I., 1989. Strontium isotope studies of atmospheric inputs to forested watersheds in New Mexico. Biogeochemistry 8, 115-134.

Graustein, W.C., 1989. ${ }^{87} \mathrm{Sr} /{ }^{86} \mathrm{Sr}$ ratios measure the sources and flow of strontium in terrestrial ecosystems. In: Rundel, P.W., Ehleringer, J.R., Nagy, K.A. (Eds.), Stable Isotopes in Ecological Research. Springer-Verlag, New York, pp. 491-512.

Graustein, W.C., Armstrong, R.L., 1983. The use of strontium-87/strontium-86 ratios to measure atmospheric transport into forested catchments. Science 219, 289-292.

Li, C., Li, X., Li, Q., Guo, J., Li, X., Yang, Y., 2012. Rapid and precise determination of Sr and $\mathrm{Nd}$ isotopic ratios in geological samples from the same filament loading by thermal ionization mass spectrometry employing a single-step separation scheme. Anal. Chim. Acta 727, 54-60.

Löfvendahl, R., Åberg, G., Hamilton, P.J., 1990. Strontium in rivers of the Baltic Basin. Aquat. Sci. 52, 315-329.

Mattauer, M., Matte, P., Malavieille, J., Tapponnier, P., Maluski, H., Ku, Z., Lu, Y., Tang, Y., 1985. Tectonics of the Qinling Belt: build-up and evolution of eastern Asia. Nature 317, 496-500.

National Environmental Protection Bureau (NEPB), 2002. Standard Methods for the Examination of Water and Wastewater (Version 4). China Environmental Science Publish Press, Beijing (in Chinese).

Palmer, M.R., Edmond, J.M., 1989. The strontium isotopic budget of the modern ocean. Earth Planet. Sc. Lett. 92, 11-26.

Palmer, M.R., Edmond, J.M., 1992. Controls over the strontium isotope composition of river water. Geochim. Cosmochim. Ac 56, 2099-2111.

Pett-Ridge, J.C., Derry, L.A., Barrows, J.K., 2009. Ca/Sr and ${ }^{87} \mathrm{Sr} /{ }^{86} \mathrm{Sr}$ ratios as tracers of $\mathrm{Ca}$ and $\mathrm{Sr}$ cycling in the Rio Icacos watershed, Luquillo Mountains. Puerto Rico, Chem. Geol. 267, 32-45.

Phillips, D.L., Gregg, J.W., 2001. Uncertainty in source partitioning using stable isotopes. Oecologia 127, 171-179.

Shand, P., Darbyshire, D.P.F., Love, A.J., Edmunds, W.M., 2009. Sr isotopes in natural waters: applications to source characterisation and water-rock interaction in contrasting landscapes. Appl. Geochem. 24, 574-586.

Stallard, R.F., 1985. River chemistry, geology, geomorphology and soils in the Amazon and Orinoco basins. In: Drever, J.I. (Ed.), The Chemistry of Weathering. D. Reidel, New York, pp. 293-316.

Tripathy, G.R., Goswami, V., Singh, S.K., Chakrapani, G.J., 2010. Temporal variations in $\mathrm{Sr}$ and ${ }^{87} \mathrm{Sr} /{ }^{86} \mathrm{Sr}$ of the Ganga headwaters: estimates of dissolved $\mathrm{Sr}$ flux to the mainstream. Hydrol. Process 24, 1159-1171.

Wadleigh, M.A., Veizer, J., Brooks, C., 1985. Strontium and its isotopes in Canadian rivers: fluxes and global implications. Geochim. Cosmochim. Ac. 49, 1727-1736.

Wu, W., Xu, S, Yang J. Yin, H., Tao, X, 2009. Sr fluxes and isotopic compositions in the headwaters of the Yangtze river, Tongtian river and Jinsha river originating from the Qinghai-Tibet Plateau. Chem. Geol. 260, 63-72.

Xu, Z., Shi, C., Tang, Y., Han, H., 2011. Chemical and strontium isotopic compositions of the Hanjiang Basin Rivers in China: anthropogenic impacts and chemical weathering. Aquat. Geochem 17, 243-264.

Zhai, X., Day, H.W., Hacker, B.R., You, Z., 1998. Paleozoic metamorphism in the Qinling orogeny, Tongbai Mountains, central China. Geology 26, 371-374. 